\title{
Strategi Pemuda Gang Tato Desa Kemantren Kabupaten Malang Melawan Stigma Sosial
}

\author{
Risdawati Ahmad ${ }^{1}$ \\ Fakultas Ilmu Sosial, Universitas Negeri Malang \\ Malang, Indonesia \\ risdawatiahmad@gmail.com \\ Joan Hesti Gita Purwasih ${ }^{2}$ \\ Fakultas Ilmu Sosial, Universitas Negeri Malang \\ Malang, Indonesia \\ joan.hesti.fis@um.ac.id \\ Irawan $^{3}$ \\ Fakultas Ilmu Sosial, Universitas Negeri Malang \\ Malang, Indonesia \\ sosantira@gmail.com
}

\begin{abstract}
This thesis attempts to review how the Young People of Tattoo Alley interpret tattoos and social movements carried out to fight stigma. The process of extracting data is done through a qualitative approach. This study uses data collection techniques such as observation, interviews and documentation. The research location is in Tattoo Alley, Kemantren Village, Malang Regency. The process of data analysis is done through data collection, data reduction, data presentation, and drawing conclusions. Meanwhile, the validity of the data was examined using source triangulation techniques. The results of this study indicate that: First, there are two types of meaning of tattoos that are distinguished by phase, namely the first phase of meaning of tattoos tends to be negative, while the second phase of tattoos is more positively interpreted. Second, forms of social movements undertaken by Tattoo Alley Young People to fight stigma and discrimination include: conducting tutoring, training in mask craft, training in traditional musical instruments, and implementing teaching programs conducted by thugs. Keywords: the young people of tattoo alley, social movements, social construction, social stigma, tattoos

Abstrak

Tulisan ini berusaha mengulas bagaimana pemuda Gang Tato memaknai tato dan gerakan sosial yang dilakukan untuk melawan stigma. Proses penggalian data dilakukan melalui pendekatan kualitatif. Penelitian ini menggunakan teknik pengumpulan data berupa observasi, wawancara dan dokumentasi. Lokasi penelitian terletak di Gang Tato, Desa Kemantren,
\end{abstract}


Kabupaten Malang. Proses analisis data dilakukan melalui pengumpulan data, reduksi data, penyajian data, dan penarikan kesimpulan. Sedangkan keabsahan data diperiksa menggunakan teknik triangulasi sumber. Hasil penelitian ini menunjukan bahwa: Pertama, terdapat dua jenis pemaknaan tato yang dibedakan beradasarkan fase, yaitu fase pertama pemaknaan tato cenderung negatif, sedangkan fase kedua tato lebih dimaknai secara positif. Kedua, bentuk gerakan sosial yang dilakukan oleh pemuda Gang Tato untuk melawan stigma dan diskriminasi antara lain: mengadakan bimbingan belajar, pelatihan membuat kerajinan topeng, pelatihan alat musik tradisional, dan pelaksanaan program preman mengajar.

Kata Kunci: pemuda gang tato, gerakan sosial, konstruksi sosial, stigma sosial, tato

Diterima tgl bulan tahun, Dipublikasikan tgl bulan tahun

\section{PENDAHULUAN}

Manusia memiliki rasa, ide, kreativitas, dan estetik sepanjang peradaban. Salah satunya dengan mengurangi, menambah, atau mengubah bagian tubuh alamiahnya. Hal tersebut bisa dilakukan oleh individu maupun kelompok baik secara wajib, sukarela atau bahkan karena terpaksa. Pengubahan ini mempunyai tujuan yang beragam dan dapat berubah dari waktu ke waktu serta berbeda antara budaya yang satu dengan budaya yang lain.

Bagi sebagian orang, tubuh adalah media yang tepat untuk menuangkan ekspresi, sehingga tidak heran jika kemudian muncul aktivitas mendekorasi tubuh seperti body painting, piercing, dan tato. Pada awalnya, aktivitas mendekorasi tubuh dilakukan untuk tujuan khusus, yaitu bagian dari ritual kebudayaan (Pelamonia, 2016). Seseorang dapat membentuk tubuhnya melalui berbagai cara, sehingga tubuh kemudian menjadi simbolisasi bagi individu maupun kelompok (Gumilar, 2008). Lebih lanjut, tubuh menjadi simbolisasi karena posisinya sangat vital yaitu sebagai ruang perjumpaan antara individu dan sosial, ide dan materi, sakral dan profan, serta transanden dan imanen (Brunner, 1986). Hal ini menjadikan tubuh tidak saja menjadi perantara bagi masuknya pengalaman ke dalam diri, melainkan juga menjadi perantara bagi seseorang untuk mengaktualisasikan dan mengekspresikan diri. Definisi tato menurut (Olong, 2006) dalam bukunya yang berjudul "Tato", adalah proses menandai kulit menggunakan pola atau design secara permanen dengan membubuhkan dan memasukkan cairan berwarna.

Kini di Indonesia, tato banyak dijumpai di daerah perdesaan maupun perkotaan (Fattahurrosyid, 2016), dimana penggunanya telah mencabut makna tato dari habitat aslinya. Sebagian masyarakat yang tertarik pada tato menggunakannya sesuka hati sebagai bentuk pengekspresian diri. Penggunaan tato disalahgunakan oleh preman agar dirinya terkesan menakutkan. Tato juga pernah dijadikan sebagai tanda untuk narapidana yang bebas dari penjara (Yoba, 2012). Sehingga kini tato mengalami perubahan image dari yang sebelumnya berkaitan dengan tradisi bergeser menjadi tanda sebuah kriminal (Olong, 2006). Peristiwa besar yang berkaitan dengan orang bertato pernah terjadi pada periode tahun 1982-1985 (masa orde baru), peristiwa ini disebut Petrus (Penembak Misterius) yang dilakukan oleh negara melalui aparatur militernya. 


\section{Strategi Pemuda Gang Tato Desa Kemantren Kabupaten Malang Melawan Stigma Sosial}

Dewasa ini eksistensi tato dianggap sebagai bagian dari patologi sosial, yaitu tindakan yang keluar dari nilai dan norma masyarakat. Indonesia sendiri khususnya di wilayah-wilayah perdesaan masih menjadikan konformitas sebagai penilaian terhadap baik buruknya perilaku seseorang. Masyarakat menilai orang yang normal, berpenampilan baik dan alim apabila tubuhnya bersih dari tinta yang dihasilkan oleh tato maupun tindik (Sanjaya and Sukendro, 2019). Jika terlihat sedikit saja tato dan tindik di tubuhnya maka ia akan mendapatkan celaan atau gunjingan yang berakhir pada pemberian stigma negatif dari masyarakat.

Sebagaimana yang telah disinggung di atas, bahwa fenomena orang bertato tidak hanya ditemukan di kota-kota besar, melainkan juga di wilayah perdesaan. Seperti halnya di Kabupaten Malang, terdapat sebuah perkampungan yang mayoritas penduduk laki-lakinya menggunakan tato. Perkampungan tersebut terletak di Gang Tato, RT 4, RW 2, Desa Kemantren, Kecamatan Jabung, Kabupaten Malang yang memiliki jumlah penduduk sebanyak 45 KK. Penggunaan tato di gang ini sudah ada sejak tahun 1984, dan diwariskan secara turun temurun hingga tiga genarasi, yaitu generasi pertama (sebelum tahun 1990), generasi kedua (1991-2000), dan generasi ketiga (2001-2015). Ketiga generasi ini tidak lepas dari stigma negatif dan perilaku diskriminasi dari masyarakat sekitar yang menganggap tato sebagai tindakan menyimpang. Bertahannya ketiga generasi tersebut disebabkan oleh adanya proses adaptasi yang dilakukan oleh individu dengan nilai-nilai tato di lingkungannya. Namun, nilainilai ini mulai hilang ketika muncul agen yang mempengaruhi pandangan mereka terhadap tato hingga akhirnya memutuskan untuk berhenti menggunakan tato.

Berdasarkan latar belakang di atas, penulis memfokuskan kajian ini pada konstruksi sosial pemuda Gang Tato dalam memaknai tato dan bagaimana strategi mereka melawan stigma dan diskriminasi dari masyarakat. Urgensi penelitian ini adalah strategi perlawanan yang mereka lakukan dapat dijadikan rujukan bagi kampung-kampung lain untuk menyelesaikan permasalahan sejenis. Selain itu, dapat menjadi alat penyampaian informasi kepada publik mengenai strategi-strategi yang dilakukan oleh masyarakat Gang Tato, agar stigma negatif tentang orang bertato perlahan berkurang. Penelitian ini juga membuktikan bahwa tato tidak bisa dijadikan term pembenaran terhadap perlakuan buruk seseorang. Teori yang digunakan dalam penelitian ini adalah teori konstruksi sosial yang dikemukakan oleh Peter L. Berger dan Thomas Luckmann, serta teori gerakan sosial baru.

\section{METODE}

Penelitian ini menggunakan pendekatan kualitatif sebab permasalahan yang dikaji memerlukan sejumlah data lapangan yang bersifat aktual dan konseptual (Creswell, 2015). Data dalam penelitian ini terdiri dari data primer yang diperoleh langsung di lapangan melalui observasi, wawancara, dan dokumentasi, serta data sekunder yang diperoleh melalui bahan bacaan baik diperpustakaan maupun internet.

Penelitian ini dilakukan pada bulan Juni - Agustus 2019 di Gang Tato, Desa Kemantren, Kecamatan Jabung, Kabupaten Malang. Informan dalam penelitian ini adalah Pemuda Gang 


\section{Risdawati Ahmad, Joan Hesti Gita Purwasih, dan Irawan}

Tato yang dipilih menggunakan teknik penentuan informan bertujuan (purposive) dalam penelitian kualitatif. Kriteria subjek yang dijadikan informan antara lain: 1) Orang-orang yang menggunakan tato, pembuat tato dan memahami sejarah tato di Gang Tato. 2) Orang-orang yang pernah mengalami diskriminasi akibat stigma tato yang melekat pada mereka. 3) Orangorang yang menjadi aktor atau penggerak gerakan perlawan stigma di Gang Tato.

Analisis data dalam penelitian ini menggunakan model Miles dan Huberman (2002), yang terdiri dari tiga tahap analisis yaitu, pengumpulan data, reduksi data, penyajian data dan penarikan kesimpulan. Pertama pengumpulan data, Data dikumpulkan oleh peneliti berupa data hasil observasi, wawancara, dan dokumentasi yang dicatat dalam catatan lapangan. Kedua reduksi data, yang dilakukan saat peneliti melakukan proses pengumpulan data sampai data dikatakan jenuh. Data yang diperoleh dari hasil observasi, wawancara, dokumentasi, dan materi audio visual dari Gang Tato dituangkan dalam uraian/laporan lengkap dan terperinci. Ketiga penyajian data dan penarikan kesimpulan, bentuk data yang disajikan dalam penelitian ini adalah paparan teks naratif dan bagan. Berdasarkan data yang telah kumpulkan, direduksi dan disajikan, peneliti membuat kesimpulan yang didukung oleh bukti kuat.

Teori yang digunakan untuk menganalisis permasalahan ini adalah Teori Konstruksi Sosial yang dikemukakan oleh Peter L. Berger dan Thomas Luckmann (1990) serta Teori Gerakan Sosial Baru versi Alberto Melucci (1985). Konstruksi makna tato bagi pemuda Gang Tato terjadi melalui tiga tahap yaitu eksternalisasi, obyektivasi, dan internalisasi. Proses eksternalisasi merupakan suatu proses untuk mencurahkan kedirian manusia secara terus menerus kedalam dunia, baik aktivitas fisik maupun mentalnya. Proses obyektivasi yaitu proses mengkristalkan objek ke dalam pikiran, atau segala bentuk eksternalisasi yang telah dilakukan dilihat kembali pada kenyataan di lingkungan secara objektif. Proses internalisasi yaitu segala hal yang bersifat obyektif akan diserap oleh individu dan kemudian akan direalisasikan secara subyektif. Internalisasi berlangsung seumur hidup melalui proses sosialisasi.

Sedangkan teori gerakan sosial digunakan untuk menjelaskan gerakan-gerakan yang dilakukan oleh pemuda Gang Tato untuk mengubah stigma masyarakat terhadap mereka. Gerakan sosial baru yang dilakukan oleh pemuda Gang Tato merupakan gerakan-gerakan yang bersifat non-materialistik, karena tidak bertujuan untuk hal-hal yang bersifat materi seperti uang, melainkan bertujuan untuk menghapus stigma dan perilaku diskriminasi. Stigma dan perilaku diskriminatif merupakan salah satu permasalahan kemanusiaan, yang jika tidak dilawan akan berdampak buruk pada masyarakat yang mengalaminya.

\section{HASIL DAN PEMBAHASAN}

\section{Konstruksi Sosial Makna Tato Bagi Pemuda Gang Tato}

Istilah Gang Tato merujuk pada penyebutan sebuah perkampungan di Desa Kemantren, Kecamatan Jabung, Kabupaten Malang. Perkampungan yang sebelumnya dikenal dengan sebutan RT 4 RW 2 ini berubah nama menjadi Gang Tato pada tahun 1990-an. Istilah tersebut 


\section{Strategi Pemuda Gang Tato Desa Kemantren Kabupaten Malang Melawan Stigma Sosial}

disematkan oleh masyarakat sekitar karena mayoritas penduduk laki-lakinya menggunakan tato sejak tahun 1984. Penggunaan tato di gang ini dilakukan secara turun-temurun hingga tiga generasi. Ketiga generasi tersebut dikategorikan berdasarkan eksistensinya pada saat itu. Karakteristik ketiga generasi disajikan pada gambar berikut:

\begin{tabular}{|c|c|c|}
\hline $\begin{array}{c}\text { Generasi } 1 \\
(1984-1990)\end{array}$ & $\begin{array}{c}\text { Generasi } 2 \\
(1991-2000)\end{array}$ & $\begin{array}{c}\text { Generasi } 3 \\
(2001-2016)\end{array}$ \\
\hline $\begin{array}{l}\text { - Mengenal } \\
\text { tato dari } \\
\text { teman } \\
\text { seprofesi, di } \\
\text { Kota } \\
\text { Surabaya. } \\
\text { - Teknik } \\
\text { pembuatan } \\
\text { tato masih } \\
\text { tradisional, } \\
\text { yaitu } \\
\text { menggunakan } \\
\text { tangan. } \\
\text { - Memaknai tato } \\
\text { secara negatif. }\end{array}$ & $\begin{array}{l}\text { - Mengenal } \\
\text { tato dari } \\
\text { generasi ke-1 } \\
\text { dan teman } \\
\text { dari luar } \\
\text { daerah. } \\
\text { - Teknik } \\
\text { pembuatan } \\
\text { tato lebih } \\
\text { maju: } \\
\text { mengguna } \\
\text { kan dynamo } \\
\text { mobil mainan } \\
\text { sebagai } \\
\text { penggerak } \\
\text { jarum. } \\
\text { - Memaknai tato } \\
\text { secara negatif. }\end{array}$ & $\begin{array}{l}\text { - Mengenal tato } \\
\text { dari generasi } \\
\text { kedua. } \\
\text { - Teknik } \\
\text { pembuatan } \\
\text { tato } \\
\text { menggunakan } \\
\text { dynamo bekas } \\
\text { type recorder } \\
\text { - Merupakan } \\
\text { aktor utama } \\
\text { pergerakan } \\
\text { melawan } \\
\text { stigma. } \\
\text { - Memaknai tato } \\
\text { secara negatif, } \\
\text { namun berubah } \\
\text { menjadi positif } \\
\text { ketika ada } \\
\text { pengaruh agen. }\end{array}$ \\
\hline
\end{tabular}

Gambar 1. Karakteristik Generasi Pengguna Tato di Gang Tato (Data diolah Peneliti, 2020)

Menurut (Fhadila, 2017), tindakan seseorang sangat dipengaruhi oleh lingkungannya. Berdasarkan gambar di atas, diketahui terdapat beberapa perbedaan karakteristik antara generasi pertama hingga ketiga, baik cara mengenal tato, teknik pembuatan tato, maupun makna yang terbentuk dari tato. Perbedaan-perbedaan ini tidak terjadi dengan sendirinya, melainkan ada konstruksi sosial yang mempengaruhi. Istilah konstruksi sosial atas realitas (social construction of reality) didefinisikan sebagai proses sosial melalui tindakan dan interaksi dimana individu menciptakan secara terus menerus suatu realitas yang dimiliki dan dialami secara subyektif (Berger and Luckmann, 1990). Terdapat tiga proses dalam konsturksi sosial yaitu eksternalisasi, objektivasi dan internalisasi.

Makna tato yang terbentuk dari proses konstruksi sosial terbagi menjadi dua, yaitu pemaknaan yang mengarah pada hal-hal negatif dan pemaknaan yang mengarah pada hal-hal positif. Pemaknaan jenis pertama tato diidentikan dengan simbol kejahatan, selain itu mereka merasa bangga memiliki tato karena dapat membuat orang lain takut. Pemaknaan yang demikian terjadi pada kisaran tahun 1984 - 2015, yang selanjutnya oleh penulis disebut dengan 
pemaknaan fase pertama. Setelah tahun 2015 terjadi arus balik, dimana pemuda Gang Tato mulai menyadari dampak negatif penggunaan tato yaitu mereka mendapat stigma dari masyarakat sekitar. Kesadaran inilah yang membuat mereka memutuskan untuk berhenti menggunakan tato dan semua aktivitas yang berhubungan dengan tato. Fase inilah yang penulis sebut sebagai fase kedua. Baik fase pertama maupun kedua tidak terlepas dari pengaruh konstruksi sosial yang menyebabkan mereka menggunakan tato, dan kemudian memutuskan untuk berhenti menggunakan tato. Kedua fase ini sama-sama terjadi melalui tahapan eksternalisasi, objektivasi dan internalisasi. Untuk memudahkan pembaca memahami alur konstruksi ini, penulis menyajikan bagan berikut: 
FASE 1 (1984-2015)

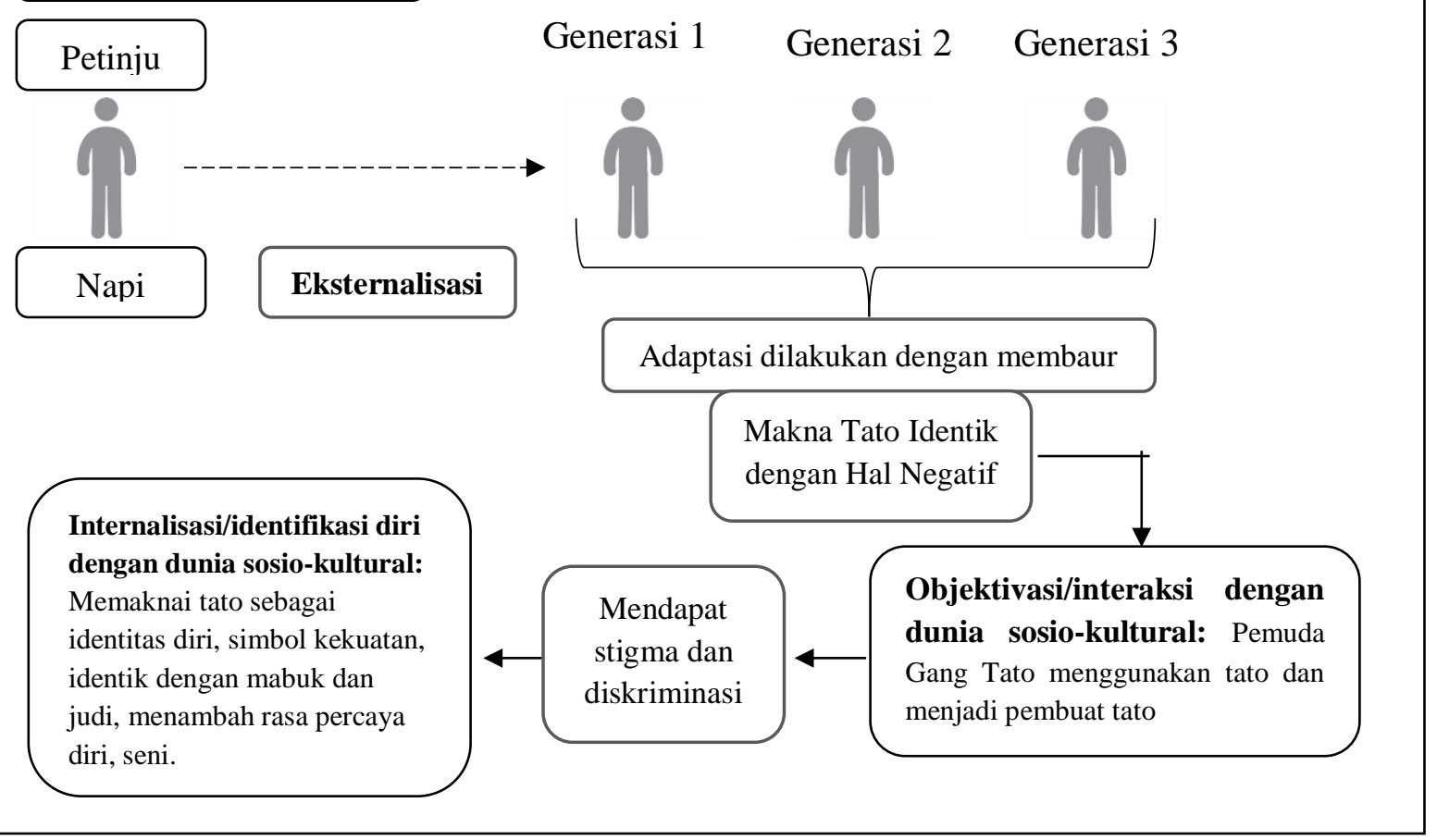

FASE 2 (2016 - Sekarang)

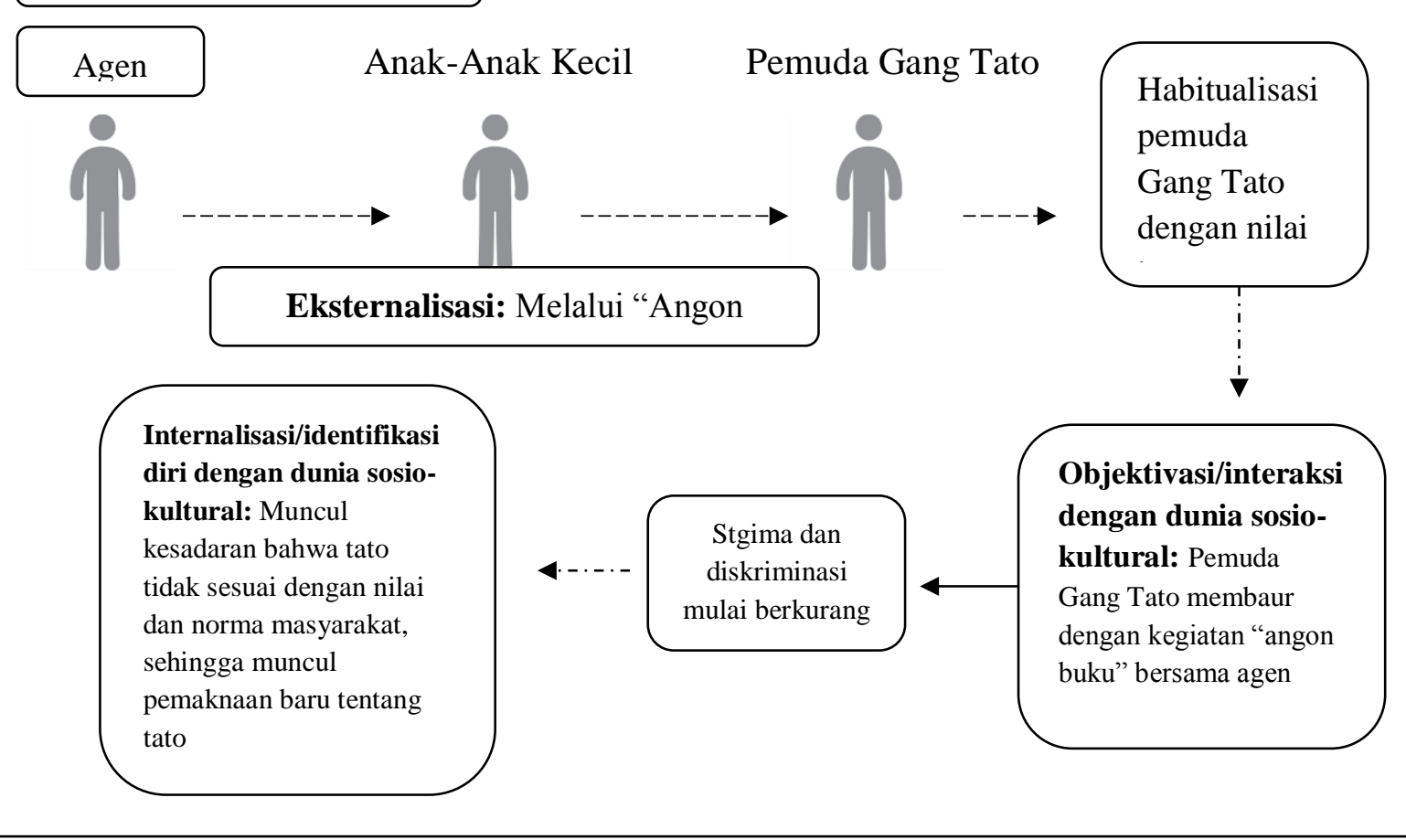

Gambar 2. Proses Konstruksi Sosial Pemaknaan Tato Pada Fase Kedua (Data diolah Peneliti, 2020) 
Tahapan awal pembentukan konstruksi sosial pada fase pertama adalah bagaimana mereka membentuk makna tato, sehingga tertarik untuk menggunakannya. Ketiga generasi tersebut memiliki pemaknaan tato yang berbeda, karena cara pengkonstruksian dan lingkungan yang mempengaruhinya pun berbeda. Menurut (Sepa et al., 2019), lingkungan sangat berpengaruh terhadap pola pikir seseorang. Selain itu, menurut (Handoko, 2010), perbedaan makna tato juga dipengaruhi oleh subjek yang memaknainya.

Makna tato pada pengguna tato generasi pertama adalah tato dapat memberikan kesan menakutkan kepada orang lain, simbol kekuatan, simbol kekuasaan, dan identik dengan kebiasaan mabuk dan berjudi. Generasi kedua juga memiliki pemaknaan yang hampir sama dengan generasi pertama, akan tetapi pada generasi ini selain menggunakan tato mereka juga menerima jasa pembuatan tato, sehingga tato dimaknai sebagai sumber penghasilan ekonomi. Sedangkan pemaknaan pada generasi ketiga sudah mulai beragam, generasi ini memaknai tato sebagai bentuk identitas diri yang berfungsi untuk menunjukkan kepada masyarakat bahwa mereka adalah pemuda-pemuda Gang Tato yang terkenal menakutkan, serta bagi mereka tato dapat meningkatkan rasa percaya diri.

Proses pembentukan makna menurut (Husserl, 1962) dimulai dari kesadaran, kesengajaan, hingga pengetahuan individu terhadap objek. Kesadaran yang dimaksud adalah bagaimana para pengguna tato memandang dan menilai tato. Kemudian kesengajaan mereka terlibat dalam dunia tato merupakan bentuk keputusan mereka berdasarkan penilaiannya terhadap tato. (Mukhlis et al., 2018), menjelaskan bahwa terdapat faktor pemicu yang mempengaruhi tindakan dan perilaku seseorang. Melalui konstruksi makna dan realitas sosial tato yang dilakukannya, pemuda Gang Tato mengkonstruksi makna tato berdasarkan pengalaman yang mereka peroleh dari lingkungannya. Pengalaman ini didapat melalui proses adaptasi yang dikenal dengan istilah eksternalisasi. Eksternalisasi adalah tahap individu beradaptasi dengan dunia sosio-kulturalnya sebagai produk manusia (Berger and Luckmann, 1990). Eksternalisasi juga disebut sebagai proses untuk mencurahkan kedirian manusia secara terus menerus ke dalam dunia, baik aktivitas fisik maupun mentalnya (Bungin, 2008).

Terdapat beberapa faktor yang melatarbelakangi pemuda Gang Tato memiliki ketertarikan terhadap tato dan mulai melakukan adaptasi. Penulis merujuk pada kajian motivasi, tujuan, konsep, dan gagasan lainnya dari pemikiran (Schutz, 1932) untuk melihat faktor-faktor pendukung tersebut. Berdasarkan hasil analisis, beberapa faktor yang mendukung ketertarikan pemuda Gang Tato terhadap tato antara lain motivasi internal, motivasi eksternal, keterampilan, dan tujuan. Ketertarikan inilah yang menciptakan makna tato bagi pemuda Gang tato. Untuk menggambarkan analisis ini penulis menyajikan diagram berikut: 


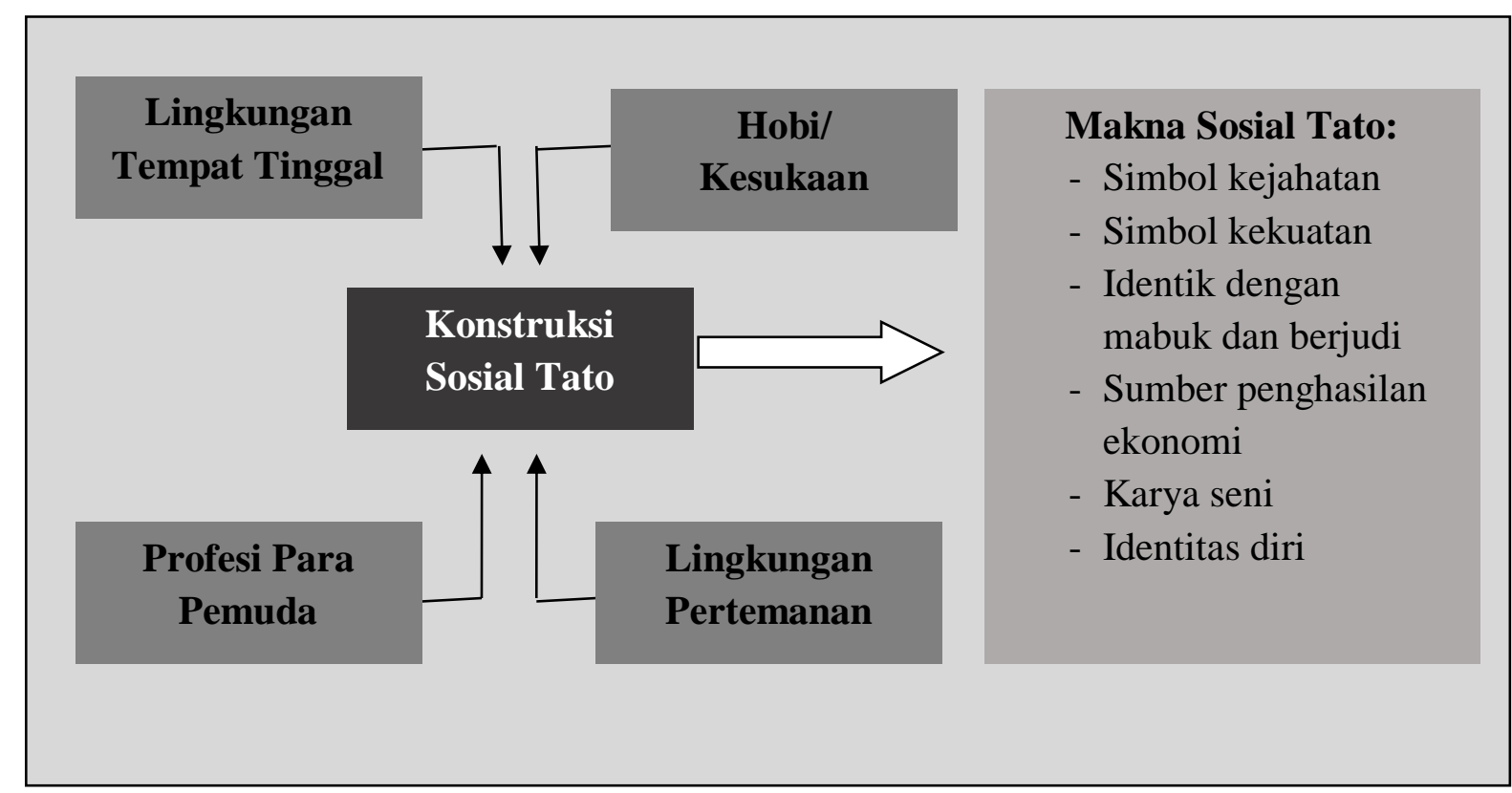

Gambar 3. Model Konstruksi Makna Tato Bagi Pemuda Gang Tato (Data diolah Peneliti, 2020)

Motivasi internal yang dimaksud adalah timbulnya rasa suka, hobi dan ketertarikan individu terhadap bentuk tato itu sendiri. Pada fase pertama ini (1984 - 2015) terdapat beragam alasan mengapa generasi pertama hingga ketiga menggunakan tato. Sebagian besar dari mereka mengaku mencintai keindahan seni dan hobi menggambar khususnya di media kulit karena lebih menantang. Rasa suka terhadap tato inilah yang kemudian menyebabkan mereka menggunakan tato dan menjadi pembuat tato hingga kampungnya dikenal sebagai Gang Tato. Banyak pemuda-pemuda dari luar daerah menggunakan jasa mereka karena dari segi harga sangat terjangkau yaitu berkisar Rp 100.000 - Rp 200.000 per tato tergantung tingkat kerumitannya. Selain itu, mereka juga menggunakan peralatan yang didesain sendiri dari barang-barang bekas, seperti dynamo mobil mainan dan dynamo type recorder untuk menggerakan jarum.

Faktor pemicu berikutnya adalah motivasi eksternal yang mengkonstruksi makna tato kepada pemuda Gang Tato yaitu lingkungan, seperti lingkungan keluarga, teman dan dari informasi di media massa (Dasopang and Montessori, 2018; Schutz, 1999). Faktor eksternal merupakan faktor terkuat dalam mempengaruhi pemuda Gang Tato. Generasi pertama menggunakan tato karena dipengaruhi oleh lingkungan pekerjaan yaitu pada tahun 1984 ia bekerja sebagai petinju di salah satu sanggar di Kota Surabaya. Melalui interaksi yang dilakukan secara terus menerus dengan teman-temannya menyebabkan informan dari generasi pertama ini tertarik untuk menggunakan tato. Ia menganggap tato sebagai pendukung penampilannya saat bertinju, karena dapat memberikan kesan menakutkan. Pernyataan ini sejalan dengan pendapat (Hendrawan, 2001), bahwa pada tahun 1990-an tato merupakan trend 


\section{Risdawati Ahmad, Joan Hesti Gita Purwasih, dan Irawan}

di kalangan petinju karena dapat mempengaruhi mentalitas lawannya. Selain pekerjaan, kebijakan pemerintah untuk menato tubuh narapidana juga turut membentuk makna tato itu sendiri. Pengguna tato generasi pertama pernah dipenjara pada tahun 1983. Saat itu terjadi peristiwa Petrus (Penembak Misterius) yang mewajibkan seluruh narapidana di Indonesia ditato sebagai tanda bahwa ia adalah seorang penjahat (Aprili et al., 2016).

Makna tato yang dimiliki generasi pertama kemudian dikonstruksi oleh generasi selanjutnya melalui komunikasi internal dalam bentuk saling bertukar informasi mengenai hal-hal yang berkaitan dengan tato. Para pengguna tato ini biasanya berkumpul untuk bertukar informasi tentang alat dan bahan yang digunakan untuk menato. Pengetahuan tentang teknik pembuatan tato juga didukung oleh lingkungan pertemanan mereka. Sekitar tahun 1990-an teman pemuda Gang Tato yang merupakan pembuat tato dari daerah lain berkunjung ke Gang Tato dan mengajarkan teknik pembuatan tato kepada mereka. Berawal dari sinilah pemuda Gang Tato mulai mahir membuat tato.

Sama halnya dengan konstruksi makna dan realitas sosial tato pada generasi ketiga yang juga dipengaruhi oleh lingkungannya. Antar generasi pengguna tato di Gang Tato sebagian besar memiliki hubungan keluarga, khususnya generasi kedua dan ketiga. Hubungan keluarga inilah yang memberikan pengaruh cukup besar dalam mengkonstruksi makna tato pada anggota keluarganya yang lain. Mereka tumbuh dan berkembang di lingkungan yang mayoritas penduduknya menggunakan tato, sehingga tato sudah dianggap hal yang wajar dan keharusan bagi penduduk disini, mengingat nama perkampungan mereka sendiri adalah Gang Tato.

Faktor terakhir yang mempengaruhi ketertarikan pemuda Gang Tato terhadap tato adalah tujuan mereka menggunakan tato. Antar individu dalam tiga generasi memiliki tujuan yang berbeda. Sebagaimana informan yang termasuk generasi pertama menggunakan tato untuk memberikan rasa takut kepada lawannya dalam pertandingan tinju, karena pengguna tato pada saat itu dipandang kuat secara fisik (Pradita, 2013). Sedangkan tujuan menggunakan tato bagi informan-informan yang termasuk generasi kedua adalah sebagai sumber penghasilan ekonomi, karena mereka menjadikan tato sebagai profesi. Terakhir adalah tujuan dari informan yang termasuk generasi ketiga, sebagian besar dari mereka memiliki tujuan untuk menyalurkan bakat seni dan sebagai identitas diri.

Pemaknaan tato dari ketiga generasi memang beragam, akan tetapi pada fase pertama ini tato diidentikkan dengan kebebasan, termasuk bebas melakukan perbuatan menyimpang, seperti mabuk dan berjudi. Berdasarkan hasil wawancara, informan mengaku bahwa ketika tato mulai berkembang di Gang Tato, secara bersamaan para pemudanya memiliki kebiasaan buruk, bahkan hampir setiap hari sepanjang jalan gang tersebut dipenuhi dengan orang mabuk dan berjudi. Hal ini karena setelah mengenal tato, jaringan mereka dengan sesama pengguna tato di luar daerahnya semakin luas. Orang-orang baru yang mereka kenal ternyata memiliki perilaku buruk, sehingga berpengaruh buruk juga terhadap perilaku pemuda Gang Tato.

Berdasarkan penjelasan di atas, faktor-faktor pendukung yang disebutkan menurut (Husserl, 1962) adalah bentuk kesadaran pemuda Gang Tato dalam proses memaknai tato. Dari 


\section{Strategi Pemuda Gang Tato Desa Kemantren Kabupaten Malang Melawan Stigma Sosial}

kesadaran ini muncul beragam makna tato yang kemudian menyebabkan mereka menggunakan tato. Keputusan untuk menggunakan tato dalam proses pengkonstruksian makna tato merupakan bentuk kesengajaan (Husserl, 1962). Atau dengan kata lain disebut juga dengan objektivasi, yaitu proses mengkristalkan objek ke dalam pikiran, atau segala bentuk eksternalisasi yang telah dilakukan dilihat kembali pada kenyataan di lingkungan secara objektif (Bungin, 2008). Terdapat dua komponen dalam objektivasi, yaitu institusionalisasi dan habitualisasi. Institusionalisasi merupakan proses membangun kesadaran menjadi tindakan (Bungin, 2008). Sebagaimana pemuda Gang Tato yang setelah memiliki kesadaran terhadap makna tato, kemudian mereka mulai menggunakan tato. Penggunaan tato disertai dengan tindakan menyimpang yang dilakukan secara terus menerus hingga tiga generasi ini menjadi kebiasaan mereka atau dikenal dengan istilah habitualisasi (Sulaiman, 2016).

Akibat dari kebiasaan yang menyimpang, masyarakat Gang Tato mendapat stigma dan diskriminasi dari lingkungan sekitarnya. Stigma yang diterima antara lain, hukum tato bagi agama tertentu adalah haram, dipandang rendah dan kemampuannya diragukan oleh masyarakat, dipandang sebagai anak nakal, dipandang tidak mampu mengurus dirinya sendiri, sehingga tidak dipercaya mengurus rumah tangga, orang yang merugi karena merusak dan menyiksa tubuhnya sendiri, menyalahi nilai-nilai etika dan moral, identik dengan dunia kriminal. Sedangkan perilaku diskriminasi yang sering diterima antara lain, tidak diterima saat melamar pekerjaan disalah satu perusahaan peternakan, sehingga menyebabkannya menjadi pengamen, tidak memperoleh penerimaan sosial, dibuktikan dengan para orang tua yang melarang anak mereka bergaul dengan pemuda Gang Tato, pernah diusir ketika berkunjung ke rumah temannya, mengalami permasalahan dalam hubungan percintaan.

Stigma dan perilaku diskriminasi yang dialami oleh pemuda Gang Tato menyebabkan keresahan bagi Irul Alamsyah, seorang penggiat sosial di Desa Kemantren. Ia disebut sebagai agen dalam penelitian ini. Agen inilah yang berusaha mengubah cara pandang pemuda Gang Tato, bahwa tato dan tindakan menyimpang mereka tidak sesuai dengan nilai dan norma masyarakat sehingga harus ditinggalkan. Harapannya adalah untuk memutus mata rantai stigma kepada generasi-generasi berikutnya. Upaya ini dilakukan pada tahun 2016 atau disebut dengan fase kedua atau fase dimana pemuda Gang Tato mulai beradaptasi dengan nilai-nilai baru yang dikonstruksi oleh agen.

Sebagai orang asing di Gang Tato, agen mengalami sejumlah hambatan dalam mengkonstruksikan nilai-nilai yang dibawa. Penolakan dan perlakuan kurang menyenangkan sering diterima. Akan tetapi, agen melakukan sejumlah upaya agar diterima dalam kelompok tersebut. Tahap pertama yang dilakukan adalah mengubah pandangan dan perilaku mereka melalui pembiasaan berinteraksi dengan hal-hal positif. Proses adaptasi dilakukan melalui bahasa, tindakan dan pentradisian. Cara melakukan adaptasi disesuaikan dengan karakter orang yang dihadapi (Bungin, 2014). Kerasnya karakter pemuda Gang Tato menyebabkan agen memilih adaptasi melalui bahasa dan tindakan, yaitu pembiasaan terhadap tindakan-tindakan positif yang sering dilakukan di Gang Tato. 


\section{Risdawati Ahmad, Joan Hesti Gita Purwasih, dan Irawan}

Sebelum mengambil tindakan, agen melakukan observasi dan pendekatan dengan mereka selama kurang lebih 3 bulan. Pada proses ini agen menyesuaikan penampilan fisiknya dengan pemuda Gang Tato, khususnya generasi ketiga yang masih eksis pada saat itu. Ia menyesuaikan cara berpakaiannya, seperti memanjangkan rambut serta memakai gelang dan kalung berukuran besar. Observasi tersebut bertujuan untuk mengenal karakter para pemuda, setelah itu agen menentukan tindakan yang akan diambil untuk mengubah pandangan mereka terhadap tato. Salah satu cara yang dilakukan agar bisa beraktivitas di Gang Tato adalah mendekati anakanak kecil di situ melalui kegiatan yang ia namakan "Angon Buku" atau sejenis perpustakaan keliling. Tidak hanya belajar, agen juga mengajak anak-anak bermain permainan tradisional agar tidak bosan.

Kegiatan positif di Gang Tato ini bertujuan agar mereka terbiasa beradaptasi dengan kegiatan-kegiatan tersebut. Hal ini karena menurut (Berger and Luckmann, 1990), sebuah realitas harus dieksternalisasikan secara berulang-ulang agar realitas tersebut masuk dan menjadi realitas subjektif bagi mereka. Akan tetapi, dalam proses adaptasi selain kelompok yang menerima ada juga kelompok yang menolak nilai-nilai baru yang dikonstruksikan (Berger and Luckmann, 1990). Sebagian besar kelompok yang menerima adalah mereka yang sudah berkeluarga atau yang anaknya bergabung dengan kegiatan agen. Penerimaan ini karena mereka lebih memikirkan nasib anak-anaknya di masa depan. Jika perilaku menyimpang tidak dihentikan maka stigma dan diskriminatif akan berdampak juga pada anak-anaknya. Sedangkan penolakan umumnya terjadi pada pemuda Gang Tato yang statusnya belum berkeluarga. Mereka menganggap dirinya masih bebas karena belum ada keluarga yang dipikirkan.

Tahap selanjutnya dari pengkonstruksian fase kedua ini adalah objektivasi. Pada tahap ini agen sudah berhasil mengajak beberapa pemuda untuk bergabung membantunya berkegiatan di Gang Tato. Salah satunya adalah Lukas yang dulunya termasuk pengguna tato generasi ketiga. Ia memilih bergabung karena ingin kegiatan positif di kampungnya semakin meluas dan berharap dapat mengubah pola pikir para pemuda serta masyarakat luas dalam menilai mereka. Setelah bergabung dengan agen, mereka berusaha mengurangi kebiasaan membuat tato, karena tato dianggap penyebab perilaku menyimpang.

Setelah bergabung, agen berusaha menyalurkan bakat-bakat yang dimiliki para pemuda. Sebagai mantan seniman tato, tentunya mereka memiliki kreativitas yang cukup tinggi. Melalui proses diskusi, agen mengidentifikasi bakat masing-masing pemuda, di antaranya bermain alat musik tradisional, pengrajin topeng, dan membuat sketsa wajah. Bakat-bakat tersebut kemudian dikembangkan dan diajarkan kepada anak-anak yang tergabung dalam kegiatan "Angon Buku". Setelah dirasa cukup mapan, agen mengajak pemuda-pemuda tersebut untuk membangun gubuk baca yang akan dijadikan sebagai tempat beraktivitas. Pembangunannya dilakukan secara gotong royong dan diberi nama Gubuk Baca Gang Tato.

Berdirinya Gubuk Baca Gang Tato membuat pemuda-pemuda di kampung ini merasa malu jika masih berperilaku negatif, sementara anak-anak kecil yang juga termasuk anak mereka 


\section{Strategi Pemuda Gang Tato Desa Kemantren Kabupaten Malang Melawan Stigma Sosial}

sedang belajar dan beraktivitas di gubuk. Hal inilah yang menyebabkan mereka mulai mengurangi mabuk dan berjudi serta menghentikan aktivitas pembuatan tato. Setelah melakukan perubahan, banyak respon positif yang mereka terima dari lingkungannya, seperti mendapat kepercayaan dari masyarakat hingga mendapat penghargaan dari IJTI (Ikatan Jurnalis Televisi Indonesia) atas dedikasinya dalam bidang pendidikan.

Pada tahap ini, tindakan mereka telah menjadi sikap hidup yang habitual, sehingga secara otomatis resposibilatas mereka terhadap tato telah membentuk sebuah pandangan yang berbeda, sebelumnya mereka menggunakan tato agar dipandang kuat dan ditakuti oleh orang lain kini berubah menjadi pandangan yang lebih progresif, dimana mereka menyadari bahwa tato tidak sesuai dengan budaya masyarakat. Sikap mereka dilatar belakangi oleh konteks sosial dan argumentasi dalam aktivitas sehari-hari.

Tahap terakhir dari proses konstruksi sosial makna tato pada fase kedua yaitu internalisasi. Internalisasi dimaknai sebagai pemahaman atau penafsiran yang langsung dari suatu peristiwa obyektif sebagai pengungkapan makna, artinya sebagai manifestasi dari proses-proses subjektif bagi individu itu sendiri (Berger and Luckmann, 1990). Pada tahap ini pemuda Gang Tato memberikan pemaknaan baru terhadap tato. Makna baru yang muncul yaitu tato dianggap sebagai perantara mereka melakukan tindakan menyimpang dan mendapat stigma dari masyarakat sekitar. Sejak pandangannya terhadap tato berubah, para pemuda mulai fokus melakukan kegiatan di Gubuk Baca Gang Tato. Hal ini dilakukan untuk memperbaiki penilaian masyarakat sekitar terhadap kampung mereka.

\section{Gerakan Sosial Pemuda Gang Tato Melawan Stigma}

Setelah terbentuknya konstruksi bahwa tato tidak sesuai dengan nilai dan norma masyarakat, pemaknaan tersebut berubah, mereka tidak lagi menggunakan tato untuk hal-hal negatif. Meskipun demikian, stigma dan perilaku diskriminatif belum bisa hilang jika belum ada pembuktian bahwa perilaku mereka telah. Salah satu bentuk pembuktiannya yaitu melakukan hal bermanfaat bagi lingkungannya. Pada sub bab ini dijelaskan mengenai upaya yang dilakukan pemuda Gang Tato untuk mengubah stigma tersebut.

Untuk menganalisis permasalahan ini peneliti menggunakan teori gerakan sosial baru. Gerakan Sosial Baru bergerak dari anti-rasialisme, anti-nukliarisme, pelucutan senjata, feminism, lingkungan, regionalism, etnitas, kebebasan sipil, dan sebagainya, hingga pada isuisu kebebasan personal dan perdamaian (Cohen, 1985; Melucci, 1985). Penelitian ini sesuai dengan teori Gerakan Sosial Baru versi Alberto Melucci (1985). Gerakan sosial dipicu oleh situasi baru dari konflik yang terjalin dengan kehidupan sehari-hari, konflik itu sendiri meliputi kode-kode simbolik, tuntutan-tuntutan identitas, dan tuntutan-tuntutan personal atau ekspresif (Melucci, 1985).

Terdapat beberapa kegiatan yang dilakukan pemuda Gang Tato untuk membuktikan pada masyarakat bahwa mereka telah berubah dari yang dulunya berperilaku negatif kini menjadi orang yang berguna untuk lingkungannya. Pertama, bimbingan belajar, kegiatan ini diikuti 
oleh anak-anak kecil baik berasal dari dalam maupun luar Gang Tato. Pemuda Gang Tato tidak memiliki kemampuan dalam bidang ini, sehingga mereka mengajak beberapa mahasiswa di kampungnya untuk bergabung dan menjadi pengajar di gubuk tersebut. Kegiatan ini dilaksanakan setiap 3 hari dalam satu minggu pada jam 18.00 - selesai.

Kedua, bidang kesenian, bakat seni pemuda Gang Tato sudah tidak diragukan lagi, mereka adalah seniman-seniman topeng yang berbakat. Selain itu mereka juga memiliki keahlian dalam bidang tari dan bermain alat musik. Bakat ini mereka tularkan kepada anak-anak di gubuk, mereka mengajarkan cara membuat topeng berbahan dasar kertas, mengajarkan tarian tradisional, dan bermain alat musik.. Ketiga, bidang permainan tradisional, para pemuda Gang Tato dan agen mengkampanyekan permainan egrang hingga gang tersebut dijuluki sebagai Kampung Egrang. Tujuannya adalah untuk memperkenalkan anak-anak pada permainanpermainan jaman dulu, sehingga mereka tidak hanya terfokuskan pada gadget.

Keempat, bidang keagamaan, Desa Kemantren memiliki empat buah pondok pesantren sehingga disebut sebagai daerah santri. Pemuda Gang Tato dan agen berkolaborasi dengan para pengajar di pondok untuk mengajarkan anak-anak mengaji. Pada tahun 2017 strategi gerakan ini semakin meluas, sehingga menginspirasi terbentuknya Program Preman Mengajar. Cakupan target pada program ini lebih luas tidak hanya bergerak di Gang Tato saja. Mereka sudah mulai bergerak dalam lingkup Kecamatan. Program ini memberikan kesempatan kepada pemuda-pemuda Gang Tato untuk menggunakan bakat seninya pada hal-hal yang lebih bermanfaat.

\section{SIMPULAN}

Adapun kesimpulan yang penulis ambil dari hasil penelitian ini, yaitu pemaknaan seseorang terhadap sesuatu dapat mengalami perubahan tergantung bagaimana proses konstruksi yang mempengaruhinya. Seperti fenomena yang terjadi di Gang Tato, dimana pemaknaan tato pada dekade 1984 - 2015 identik dengan hal-hal negatif, seperti tato untuk memberikan rasa takut pada orang lain. Namun, pemaknaan ini mengalami perubahan pada dekade 2016 - sekarang. Pergerseran makna tato ini dipengaruhi oleh proses konstruksi, dimana terdapat peran agen yang berusaha mengubah pandangan pemuda Gang Tato terhadap tato agar mereka mau berhenti dari kebiasaan tatonya. Hal ini dilakukan karena tato tidak sesuai dengan nilai dan norma masyarakat setempat, sehingga jika para pemuda masih tetap menggunakan tato maka mereka akan mendapat stigma dan diskriminasi.

Setelah berhasil mempengaruhi para pemuda di Gang Tato, agen mengajak mereka melakukan berbagai kegiatan positif untuk memperbaiki citra kampungnya yang buruk. Kegiatan tersebut antara lain, melaksanakan bimbingan belajar, melakukan pelatihan pembuatan topeng, pelatihan tari, pelatihan musik tradisional, dan sebagainya. Hal ini dilakukan agar keberadaan mereka lebih dihargai oleh masyarakat dan agar mereka terlepas dari stigma dan diskriminasi yang pernah diterima. 
Strategi Pemuda Gang Tato Desa Kemantren Kabupaten Malang Melawan Stigma Sosial

\section{UCAPAN TERIMA KASIH}

Artikel ini merupakan hasil skripsi yang publikasinya didanai oleh sumber dana PNBP Universitas Negeri Malang Tahun 2020.

\section{DAFTAR PUSTAKA}

Aprili, M.N.H., Mahadian, A.B., NurAtnan, 2016. Konsep Diri Mahasiswa Bertato di Bandung. e-Proceeding of Management 3.

Berger, P.L., Luckmann, T., 1990. Tafsir Sosial Atas Kenyataan. LP3S, Jakarta.

Brunner, E., 1986. Experience and Its Expressions dalam Bruner (ed) The Antropology of Experience. University Illinois, Chcicago.

Bungin, B., 2014. Sosiologi Komunikasi (Teori Paradigm dan Diskursus Teknologi Komunikasi di Masyarakat).

Bungin, B., 2008. Konstruksi Sosial Media Massa. Kencana Prenada Media Group, Jakarta.

Cohen, J.L., 1985. Strategy or Identity: New Theoretical Paradigms and Contemporary Social Movements. The Johns Hopkins University Press, 452.

Creswell, J., 2015. Riset Pendidikan: Perencanaa, Pelaksanaan, dan Evaluasi, Riset Kualititatif, dan Kuantitatif. Pustaka Belajar, Yogyakarta.

Dasopang, M.A., Montessori, M., 2018. Pengaruh Lingkungan dan Kebiasaan Orangtua Terhadap Perilaku dan Sikap Moral Anak 1, 10.

Fattahurrosyid, 2016. Konstruksi Realitas Sosial Tato. Jurnal Pendidikan Non-formal, 210.

Fhadila, K.D., 2017. Menyikapi Perubahan Perilaku Remaja. Jurnal Penelitian Guru Indonesia, 28.

Gumilar, G., 2008. Makna Komunikasi Simbolik di Kalangan Pengguna Tato Kota Bandung. Mediator: Jurnal Komunikasi 9, 51-62. https://doi.org/10.29313/mediator.v9i1.1140

Handoko, Cons.T., 2010. Perkembangan Motif, Makna, dan Fungsi Tato di Kalangan Narapidana dan Tahanan di Yogyakarta. Makara Human Behavior Studies in Asia 14, 107. https://doi.org/10.7454/mssh.v14i2.668

Hendrawan, L., 2001. Tato dalam Sebuah Generasi 15.

Husserl, E., 1962. General Introduction to The Pure Phenomenology. Collier Books Edition.

Melucci, A., 1985. Symbolic Challenge of Contemporary Movements. The Johns Hopkins University Press, 452.

Miles, M. B. \& Huberman, A. M. 2002. The qualitative researcher's companion. United Kingdom.

Mukhlis, S., Sanopaka, E., Ghani, N.A., Husni, A., 2018. Faktor Penyebab Perilaku Menyimpang di Kota Tanjungpinang: Studi pada Warung Kopi Pujasera Bintan Plaza, Kota Tanjungpinang 16.

Olong, H. abdul kadir, 2006. Tato. PT LKiS Printing Cemerlang, Yogyakarta.

Pelamonia, Y.K., 2016. . Transformasi Tato Pada Kaum Muda Perkotaan (Skripsi). Universitas Gajah Mada, Yogyakarta.

Pradita, M.E., 2013. TATO SEBAGAI SEBUAH MEDIA KOMUNIKASI NON VERBAL SUKU DAYAK BAHAU 1, 15.

Sanjaya, R., Sukendro, G.G., 2019. Ideologi dan Komunikasi Bob Sick Terkait Tato di Sekujur Tubuhnya Melalui Profesi. Koneksi 3, 1. https://doi.org/10.24912/kn.v3i1.6136 
Schutz, A., 1999. On Phenomenology and Social Relations : Selected Writings. The University of Chicago Press, United States.

Schutz, A., 1932. The Phenomenology of the Social World. Prendergast, Jerman.

Sepa, N.W., Bahari, Y., Fatmawati, F., 2019. ANALISIS PERGESERAN MAKNA TATO SUKU DAYAK IBAN PADA GENERASI MUDA DI DESA BATU LINTANG. Jurnal Pendidikan dan Pembelajaran Khatulistiwa, 88.

Sulaiman, A., 2016. MEMAHAMI TEORI KONSTRUKSI SOSIAL PETER L. BERGER. Society 4, 15-22. https://doi.org/10.33019/society.v4i1.32

Yoba, 2012. Representasi Tato Sebagai Identitas Diri di Kalangan Narapidana (Analisis Semiotika Tato di Kalangan Narapidana Lembaga Pemasyarakatan Maleboro Klas IIA Kota Bengkulu Tahun 2012 (skripsi). Universitas Bengkulu, Bengkulu. 